\title{
JUURNAL.RU
}

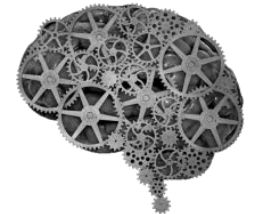

COMPANY GROUP "INTELLEKT"

\author{
Чупахин И.Н., Шкепу А.В., Василенко А.А., Денисов Д.С., Пичхидзе С.Я. \\ СГТУ имени Ю.А. Гагарина \\ Саратов, Россия
}

doi: 10.18411/lj2016-6-5-09

\section{Расчет на изгиб ножки плечевого эндопротеза}

Обычно, большое количество внутрикостных эндопротезов подвергаются нагрузке. Для того чтобы подобрать нужную конструкцию эндопротеза, её надо проверить нагрузкой на изгиб перед эксплуатацией, рис.1.

Цель работы: рассчитать нагрузку на изгиб ножки эндопротеза плечевого сустава.

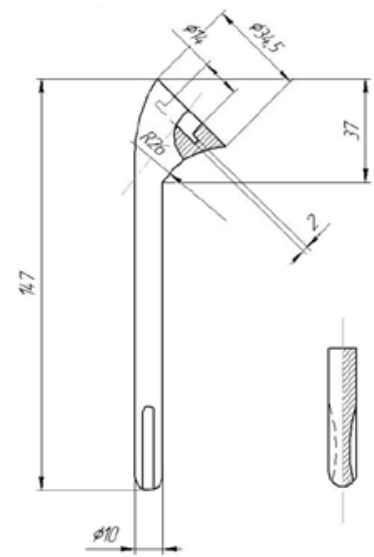

Рис.1. Схема ножки эндопротеза плечевого сустава
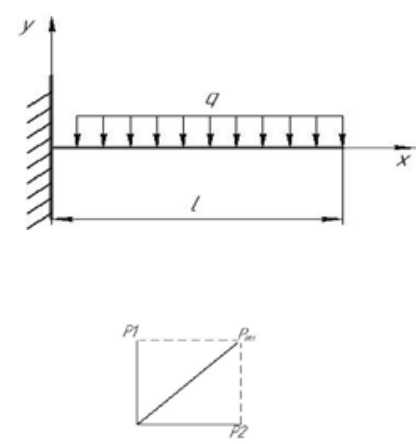

Рис.2. Консольная балка и схема расчета: $l$-длина балки, $q$ - распределенная нагрузка

Расчет проводился по консольной балке, нагруженной на изгиб, рис.2. Протез, в данном случае консольная балка, выдержит нагрузку на изгиб при условии: $\sigma \leq[\sigma]$, где: $[\sigma]-$ допустимое напряжение на изгиб для титанового сплава марки ВТ6, 410 H/мм2, б - напряжение, возникающее в материале под действием изгибающей нагрузки, $\sigma=\frac{M_{x м a x}}{W_{x}}, \mathrm{Mx}-$ изгибающий момент, $\mathrm{Mx}=$ Pрез*L, где: Ррез - изгибающая сила, H. P2peз=P21+P22. При весе человека, $\mathrm{m}$ = 
50кг, принимаем $\quad \mathrm{P} 1=\mathrm{P} 2=500 \mathrm{H}, \quad \mathrm{P}_{\text {рез }}=\sqrt{500^{2}+500^{2}}=707 \mathrm{H}$; $\mathrm{Mx}=707 \mathrm{H}^{*} 37 \mathrm{Mм}=26159 \mathrm{H} \cdot \mathrm{Mм} ; \mathrm{Wx}-$ осевой момент сопротивления, $\mathrm{W}_{\mathrm{x}}=\frac{\pi \cdot d^{3}}{32}$; где: $\mathrm{d}-$ диаметр опасного сечения, $\mathrm{d}=10 \mathrm{Mм}, W_{x}=\frac{\pi \times 10^{3}}{32}=98 \mathrm{~mm}^{3} ; \sigma=\frac{26159}{98}=$ $266 \mathrm{H} / \mathrm{MM}^{2}$;

Выводы: условие прочности $\sigma \leq[\sigma]$ соблюдается, что позволяет судить о надежности разработанной конструкции. Запас прочности на изгиб составляет 144 H/Mm2. 